\section{Primary or Secondary Synostosis: The Culmination of the Spondyloarthritis Form of Erosive Arthritis?}

\section{To the Editor:}

When are synostoses congenital in origin and when are they secondary in origin, and the result of fracture healing or an inflammatory process? Maharaj and Chandran ${ }^{1}$ suggested the publication of the first documented case of synostosis in psoriatic arthritis (PsA), a form of spondyloarthropathy (SpA). However, synostoses are well represented in the SpA record ${ }^{2,3,4}$, and perhaps even facilitate consideration and recognition of the underlying pathology ${ }^{5,6}$. Fusion of proximal radioulnar and tibiofibular joints are not only documented in current patients with $\mathrm{SpA}^{7}$, but have been documented in SpA-afflicted individuals in the archeologic and paleontologic record ${ }^{3,4,8}$. Recognized in anatomical collections (e.g., Terry collection from the earliest 20th century, curated at the National Museum of Natural History, Smithsonian Institution, Washington, DC, USA), the archeologic record documents about a $5 \%$ prevalence of this phenomenon among individuals with $\mathrm{SpA}^{3,4,6,9}$. A classic example is in the Tate Museum Columbian mammoth (Casper, Wyoming, USA). It clearly had erosions characteristic of SpA, but none present at the fused joint.

Synostoses appear to be part of the pathogenesis of the erosive joint disease characteristic of $\mathrm{PsA}^{10}$, so identification of synostosis in an individual with $\mathrm{SpA}$ does not necessarily indicate a congenital origin.

BRUCE M. ROTHSCHILD, MD, Northeast Ohio Medical University, Rootstown, Ohio 44272, and Carnegie Museum, 4400 Forbes Ave., Pittsburgh, Pennsylvania 15213, USA. E-mail: spondylair@gmail.com

\section{REFERENCES}

1. Maharaj AB, Chandran V. Unusual cause of limited elbow movement in a patient with psoriatic arthritis. J Rheumatol 2014;41:2482-3.

2. McWhirr A, Viner L, Wells C. Romano-British cemeteries at Cirencester. Cirencester Excavation Committee. Cirencester, England: Cirencester Excavation Committee; 1982.

3. Rothschild BM, Rothschild C. Nineteenth century spondyloarthropathy independent of socioeconomic status: lack of skeletal collection bias. J Rheumatol 1993;20:314-9.

4. Rothschild BM, Woods RJ. Character of precolumbian North American spondyloarthropathy. J Rheumatol 1992;19:1229-35.

5. Isidro A, Castellana C, Malgosa A. Massive tarsal ankylosis in a prehistoric skeleton. Foot Ankle Surg 2000;6:239-47.

6. Rothschild BM, Martin LD. Skeletal impact of disease. Albuquerque: New Mexico Museum of Natural History Press; 2006.

7. Resnick D. Disorders of bones and joints. Philadelphia: Saunders; 2002.

8. Rubini M, Cerroni V, Zaio P. The earliest case of spondylocarpotarsal synostosis syndrome (Roman Age-2nd century AD). Intl J Osteoarchaeol 2013;23:359-66.

9. Rothschild BM, Arriaza B, Woods RJ, Dutour O. Spondyloarthropathy identified as the etiology of Nubian erosive arthritis. Amer J Phys Anthropol 1999;109:259-67.

10. Eder L, Chandran V, Gladman DD. From ankylosis to pencil-in-cup deformity in psoriatic arthritis: a case report. Clin Exp Rheumatol 2009;27:661-3.

J Rheumatol 2015;42:6; doi:10.3899/jrheum.141631 